\title{
Security Skills Desired of Office Managers by Stakeholders: The Paticipatory Dimension
}

\author{
Adaku Ngozi Achilike \\ Department of Office Technology and Management, \\ Akanu Ibiam Federal Polytechnic, \\ Unwana, Ebonyi State, Nigeria
}

\section{Doi:10.5901/mjss.2013.v4n8p43}

\section{Abstract}

\begin{abstract}
Security is the degree of resistance to or protection from harm. It applies to vulnerable and valuable asset information, data, persons and property. The massive rate at which insecurity has ravaged nations today is the premise upon which the study on "security skills desired of Office Managers by stakeholders: The participatory dimension" was carried out. The questionnaire instrument was used for data collection from 190 respondents consisting of staff in tertiary institutions, medical fields, retired government workers and unemployed persons. Ninety-three percent (93\%) response rate was achieved while 27\% (48) females and 73\% (128) males were those whose completed questionnaires were used for analysis which attracted percentage and mean statistical tools. The decision rule accepted 3.50 mean rating and above as indication of necessity for Office Managers to acquire a given security skill while conversely, ratings below 3.50 were rejected. Only two security skills listed fell into the 'rejected category' - "ability to ensure improved performance (3.46) and "ensuring better farming techniques around" (3.49). It was established that security should be every stakeholders' concern and recommendations were proffered for (1) security laboratories to be established in institutions and administrative colleges to be used for simulations and brainstorming in training, (2) security cameras to be installed in strategic places in all the wards of the federation, (3) including security as part of the next Millennium Development Goals (MDG) phase, (4) giving free stress treatment to all those living in insecurity prone areas, among others.
\end{abstract}

Keywords: insurgency, security, stakeholders, vulnerability, participatory, documentation

\section{Introduction}

Although security has always been man's anxiety from conception, often times, the idea of it being the responsibility of first parents, next other adults, followed by institutional backgrounds surrounding man and then lately the government, especially in the present democracy; has been the trend. Security is seen by Wikipedia (2011) as the degree of resistance to or protection from harm or hazards of any type. This idea signifies or portends an element of vulnerability on the part of the entity involved such as persons, properties, documents, communities, nations, environment, etc. (en.wikipedia.org/wiki/security). In the air, sea, bush, home, on land, and so on; there is need for people to be and feel secured from harm of any type. Security has been typified into; job, global, internet, IT (computer), national, physical, finance and documentation (Information); en.wikipedia.org/wiki/job-security.

While Job security has to do with the type of job that has the probability that someone will keep his job because it guarantees good pay, good healthcare, good care after retirement; IT security has some essentials outlined for guiding the Computer against viruses, spywares and other malicious soft-wares. Courses abound that teaches on the right things to be done to keep organizations secure (www.sans.org/course/security-essentials-bootcamp-style. 
In recent times, however, security issues have taken dramatic and huge dimensions. The advanced countries saw it a long time from now and made attempts to curb, in the intent of eradicating the vice. The under-developed and developing countries are only beginning to experience the magnitude because governance has now been left in their hands in addition to tackling the menace of insecurity alongside other vices.

It was not until the September 11, 2001 Osama Bin Ladin Al Qaeda-led bombings involving USA buildings that the world realized that insecurity could also engulf the strong, hence the rich also cry. When we recall that America was really not at war and is also not Islamic, it was indeed a grave shock to the world, especially those who regarded America as the big brother that will protect them when invaded. This situation triggered up the need to be watchful over the security of citizens and properties.

The American case is that of physical with mental and economic undertone. The importance of taking a holistic look at security has now become issues of global importance. Individuals, organizations, information, environment, military and economy have taken the center stage and thus sharpened the emphasis and laying benchmark for security issues. It is therefore, obvious that without relative peace and harmonious environment, no sustainable development can be achieved. With the number of natural and man-made disasters happening daily, we cannot ignore the debilitating consequences of hunger, poverty, death, sickness, unemployment, under-development arising there from and demanding intensified security measures. This unusual times demanding unusual solutions to the daunting challenges should make room for waste free skills that can abate, if not eradicate the situation.

Although security officers/guards have been paid to protect persons and properties, there is need for the individual to apply some measures that would make their work easier. infoSec is the practice of rebuffing access to information classified as restricted. Security and safety devices abound to alert persons or companies as to illegal access to classified documents. (Car trackers are also devices aimed at security. The anti-virus measures utilized to secure documents from corruption are security devices. Examples are McAfee, Avast, Norton, among others (Jon Oltsik, 2013). Identity in the cloud and password usage is security strategies applied to save information and documents from unwanted readers.

Types of security abounds. Computer locks are advanced to avoid hacking as experienced in the V.A. suspected to be carried out by eight (8) foreign-sponsored organizations connected to the Chinese military (Washington Post, $5^{\text {th }}$ June, 2013). In security, unauthorized access is bridged for instance downloading of films and music, access to people's personal accounts. However, www.bankrate.com/finance/financial offers tips on protecting accounts and personal sensitive information from unwanted persons. It also makes available tips on being sensitive to threats and tricks while organizations are advised to block access of a terminated employee or one who resigns or retires.

National security is the requirement to maintain the survival of the state through the use of economic power, diplomacy, power projection and political power. National security aims at creating peace for citizens, animals, properties and environment. All available powers to avail citizens of confidence that they are being protected by their country should be put in place to ensure such security.

As a result of this need, change mechanism put in place must reflect the involvement of these multifacetted entities in to order achieve positive results (World Bank, 2004 in Adesola (2012). According to Madumere (2012), there is relative low awareness of students and subsequently the Nigerian public to the necessary ingredients of the environment and what constitutes changes to it and the human being around. This has impacted negatively to the demanding security measures needed for sustainable development.

The Office Manager, who constitutes one of the people in the organization is seen as the human resource whose actions, reactions and counter-actions reflect the happenings in a work system. Here it must be noted that his activities cannot be divorced from his personal, work and neighborhood environment, hence these environments if not properly considered would improve or hinder his progress. The activities of the Office Manager in the present security challenges are not shielded from harm or contributions for a better society. Unfortunately, the importance of people as vital assets in this dispensation is largely overlooked at 
this time and period and so this is reflected in the often huge losses recorded. Office Managers should be trained to avoid use of encryptions and passwords on papers/files (www.nada.org> informationtechnology>lTtips.

Documentation has in this present era been regarded as the highest innovation of our time that has engendered series of sporadic technological inventions mostly aimed at protecting nations, peoples, organizations, and environments. In spite of technology, the human person (who plans, designs, implements, sustains and makes relevant but correct changes) must be allowed to take an upper hand in developmental strides, especially in securities. Our robots, sophisticated machines and other processes require the intelligential potentials of the human person to meet desired global and local expectations, hence the need to train the human person very well in order to achieve higher performance.

\section{Educational dimension of Security Skills/Competencies}

Skills are seen as learned or developed abilities/capabilities to carry out pre-determined tasks with a view to achieving results. Survival of the individual or organizations, hinge therefore, on available skills and competencies. It is obvious in this definition that there must be a willing individual, determined to acquire the necessary abilities through repeated actions/reactions to the extent that practice makes for proficiency (en.wikipedia.org/wiki/skill).

The need for security skills hence is of no less importance in a society massively ridden with disaster tendencies. So many skill acquisition techniques have been initiated recently, especially in connection with our current amnesties. The 2003 skill acquisition model of Dreyfus and Dreyfus supported by Cheetham and Chivers (2005), Dekeyser (2009) among others has identified "novice, competence, proficiency, expertise and mastery" as the stages through which one has to go through in order to achieve good results in skill acquisition. In the model, one moves from taking instructions/orders to thinking and organizing laid down principles as gathered during the initial stage; then active decision-making concerning the tasks to developing intuition to guide decisions and finally utilizing tacit knowledge to improve, master, innovate on the tasks. There is no doubt that if this is applied in the training of graduates during schooling, security skills will be internalized and the society will be better protected.

Computer security: This implies information security as applied to the processes and mechanisms of computers and other networks. It has always been broken by hackers, thus the need to protect them. Examples include the 2010 Wikileaks saga as well as the recent (2013) Edward Snowden information leakages on US security strategies.

\section{Review of participatory dimension}

Participatory dimension was first researched in relationship with community approach to interventions in projects and general issues. It is no less relevant in security issues which have turned out to be everybody's business. Hence the need for high quality collaborations and preventions and interventions in issues of general public interest such as security especially in recent times, www.apa.org>publications>APA books. 


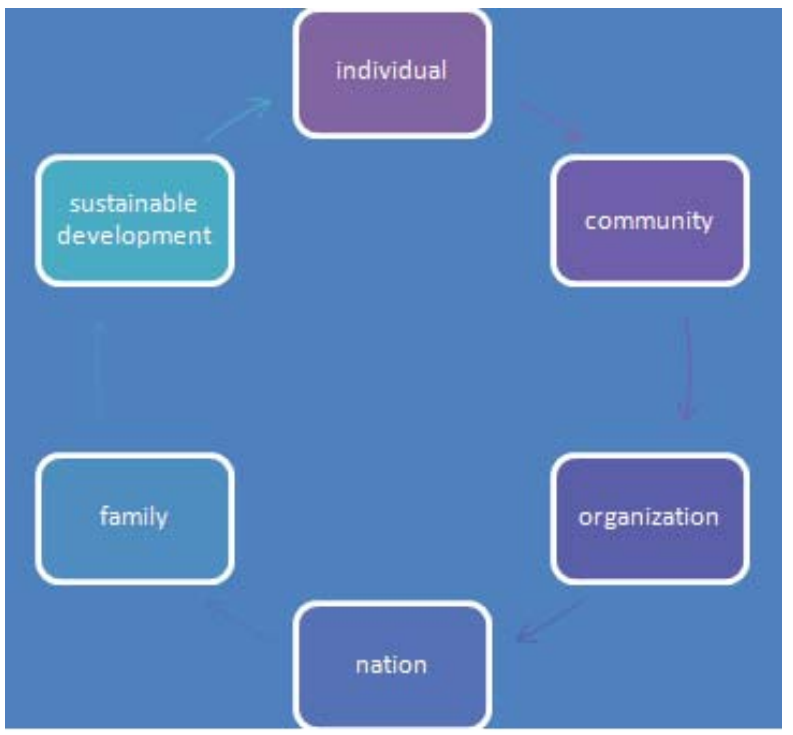

Graphic representation of Participatory dimension for global protection

\section{Problem Statement}

The issue of security has become a global case. In virtually every country, insurgency has taken root, destroying people and property. The security agents have often been taken by surprise, even when they have always promised to care for citizens. Fear seems to grip many in every nation, not knowing when the next hit will take place. Oftentimes, they tend to be woken from sleep to face the quagmire of intense security challenges, hence the need for problem solving skills in security issues. Terrorism threats have still not abated despite the awareness.

It is obvious from the foregoing that there is need for security consciousness in all nooks and cranny of the society. The home and the office of the Manager deserve to be protected as well as the family members. The care of all other belongings as well as the relations of the Manager, the supervisor/boss and neighbors are worthy of consideration. The spates of kidnappings, assassinations, and other forms of violence and premeditated murders have created the need for the issue of security to be taken more seriously and accommodate zero tolerance for complacency. The need for security skills to be imparted to students from the primary level to degree level therefore becomes very important.

Terrorism (as was tagged the September 11, 2001 saga), arson, kidnapping and abductions, environmental degradation leading to climate change, human and drug trafficking, robbery, corruption, hacking and accidents of various types have all triggered up the need for security skills and consciousness heightened by advances in technology as a result of globalization.

\section{Purpose of the Study}

The purpose of the study therefore was to identify/ascertain the security skills required by Office Managers to satisfy the yearnings of stakeholders and employers of labour globally.

Specifically, the purposes include;

1. Security skills for protecting oneself

2. Security skills for protecting documents in the office

3. Security skills required for protecting others 
4. Security skills for protecting the environment

\section{Research Questions}

1. What are the security skills required by Office Managers to protect themselves in the office setting?

2. What are the security skills required by Office Managers to protect documents from outside eyes and enemies?

3. What are the security skills required by the Office Managers to protect colleagues and others around from harm and injuries?

4. What necessary security skills are required to be exhibited by the Office Managers in order to protect their immediate and remote environment from danger, especially terrorism?

\section{Methodology}

Since security is everybody's business, the study utilized the questionnaire as design instrument for data collection, in order to obtain the opinion/views of people randomly selected from south-east and south-south zones of Nigeria. Copies of the instrument were personally administered on 190 respondents from tertiary institutions, medical professions, retired government workers and some unemployed youths. Out of the number of questionnaire distributed, $93 \%$ (176) response rate was recorded; while $27 \%$ (48) of the returned 176 questionnaires were females and the rest $(73 \%=128)$ were males.

For the questionnaire structure, 60 items of abilities were listed for respondents to indicate their importance rating. The questionnaire items were categorized into four (4) comprising:

1. Skills for protecting oneself

2. Skills for protecting documents in the office

3. Skills for protecting others

4. Skills for protecting the environments

A Likert-type 5-point scale were assigned numerical values of Very Necessary - VN (5 points), Necessary - N (4 points), Undecided - UD (3 points), Unnecessary - UN (2 points) and Very Unnecessary VUN (1 point).

The analysis attracted percentage and mean statistical tools for taking care of the data on hand. Decision rule in analysis was that 3.5 mean rating and above were regarded as acceptable in terms of the security skills needed for Office Managers to possess; while any rating(s) below 3.5 mean was regarded as not important and therefore, rejected.

\section{Distribution Rate for the Questionnaire}

\begin{tabular}{lcccc} 
Status & Total Distributed & Male & \multicolumn{3}{c}{ Female } \\
Tertiary Staff & 85 & & 61 & 24 \\
Medical Staff & 26 & 13 & 13 \\
Retiree & 22 & 13 & 9 \\
Unemployed & 57 & 42 & 15 \\
\hline Total & 190 & 129 & 61 \\
\hline
\end{tabular}

Source: Field Survey - 2013

Out of the total number, only 176 questionnaires were returned. Forty-eight (48) of them were female while 128 were males and these returned figures were utilized for the analysis. 


\section{Results Findings/Data Presentation of Analysis}

9.1 Research Question 1: Mean responses on the importance of Security skills for protecting oneself as required by Office Managers on the job.

\begin{tabular}{|c|c|c|c|c|c|c|c|c|c|c|c|c|c|}
\hline \multirow[t]{2}{*}{$\sin$} & \multirow[t]{2}{*}{ Variables } & \multirow[t]{2}{*}{ VN } & \multirow[t]{2}{*}{$\mathrm{N}$} & \multirow{2}{*}{ uo } & \multirow{2}{*}{ UN } & \multirow{2}{*}{ VuN } & \multicolumn{3}{|c|}{ Weignt } & \multirow{2}{*}{$\hat{x}$} & \multirow{2}{*}{$\bar{x}$} & \multirow{2}{*}{$\begin{array}{l}\text { Decisio } \\
\text { n }\end{array}$} & \multirow{2}{*}{$\begin{array}{l}\text { Rank- } \\
\text { ing }\end{array}$} \\
\hline & & & & & & & & 4 & $\begin{array}{lll}3 & 2 & 1\end{array}$ & & & & \\
\hline 1 & Ability to respond to enegency & 148 & 26 & 2 & 00 & 00 & 740 & 104 & $\begin{array}{lll}6 & 00 & 00\end{array}$ & 850 & 4.83 & $\begin{array}{l}\text { Accepte } \\
\text { d }\end{array}$ & $1 s t$ \\
\hline 2 & Ability to sense touble & 94 & 76 & 6 & 00 & 00 & 470 & 304 & $\begin{array}{lll}18 & 00 & 00\end{array}$ & 792 & 4.50 & A & 5 n \\
\hline 3 & Ability to exribit castion and tact & 88 & 86 & 2 & 00 & 00 & 370 & 344 & $\begin{array}{lll}6 & 00 & 00\end{array}$ & 720 & 4.09 & A & 112 \\
\hline 4 & Ability to witnhold from being nosy & 46 & 106 & 18 & 6 & 00 & 290 & 424 & $54 \quad 1200$ & 720 & 4.09 & A & $11 \pi$ \\
\hline 5 & $\begin{array}{l}\text { Ability to hold confidentality from ones, } \\
\text { especially stranges }\end{array}$ & 134 & 38 & 4 & 00 & 00 & 670 & 152 & 120000 & 834 & 4.74 & A & 2 nd \\
\hline 6 & $\begin{array}{l}\text { Ability to protect oneself from avoidable } \\
\text { danges }\end{array}$ & 98 & 78 & 00 & 00 & 00 & 490 & 312 & 000000 & 2002 & 4.56 & A & $3 r d$ \\
\hline 7 & $\begin{array}{l}\text { Ability to arange ones office as to avoid } \\
\text { accident }\end{array}$ & 96 & 72 & 8 & 00 & 00 & 480 & 288 & $24 \quad 0000$ & 792 & 4.50 & A & 5 n \\
\hline 8. & Ability to exribit honesty & 120 & 42 & 2 & 10 & 2 & 600 & 168 & $\begin{array}{lll}6 & 20 & 2\end{array}$ & 796 & 4.52 & A & $4^{n}$ \\
\hline 9 & Ability to command tust from those around & 96 & 72 & 00 & 8 & 2 & 470 & 288 & $00 \quad 16 \quad 2$ & 776 & 4.41 & A & $6 n$ \\
\hline 10 & Ability to undergo rigorous exerise & 34 & 84 & 32 & 24 & 2 & 170 & 395 & $\begin{array}{lll}96 & 48 & 2\end{array}$ & 652 & 3.71 & A & 1427 \\
\hline 11 & $\begin{array}{l}\text { Ability to rebutf compromise moves witnou: } \\
\text { huting orincuring danger to self }\end{array}$ & 78 & 82 & 10 & 6 & 00 & 390 & 328 & $90 \quad 12 \quad 00$ & 760 & 4.32 & A & $7 \mathrm{~m}$ \\
\hline 12 & $\begin{array}{l}\text { Ability to train the eas, ejes and brain to } \\
\text { sense danger }\end{array}$ & 64 & 88 & 16 & 8 & 00 & 320 & 352 & $48 \quad 8 \quad 00$ & 736 & 4.18 & A & $10 \mathrm{~m}$ \\
\hline 13 & Ability to change strategies on movenent & 44 & 100 & 28 & 4 & 00 & 220 & 400 & $84 \quad 4 \quad 00$ & 702 & 3.99 & A & $12 \mathrm{~m}$ \\
\hline 14 & Adaptability skills & 62 & 96 & 14 & 2 & 00 & 310 & 384 & $42 \quad 4 \quad 00$ & 740 & 4.21 & A & $9 n$ \\
\hline 15 & $\begin{array}{l}\text { Ability to wox with past scenes and } \\
\text { experiences }\end{array}$ & 56 & 108 & 10 & 2 & 00 & 280 & 432 & $10 \quad 200$ & 746 & 4.24 & A & $\sin$ \\
\hline 16 & Use of bullet proof vests/caps & 46 & 68 & 34 & 22 & 6 & 230 & 272 & $102 \quad 44 \quad 00$ & 654 & 3.72 & A & $13 \mathrm{n}$ \\
\hline & GRAND TOTALMEAN & & & & & & & & & 12072 & 4.29 & A & \\
\hline
\end{tabular}

The above table indicates that the respondents in considering self-security rated item 1 "ability to respond to emergency" ( $\bar{x} 4.83)$ as highest in ranking, followed by" the need for confidentiality especially with strangers" item 5 ( $\bar{x} 4.74)$. "Protecting oneself from avoidable danger" item $6(\bar{x} 4.56)$ was rated 3rd while item $8(\bar{x} 4.52)$ "exhibiting honesty" was rated 4th. However, item 16 ( $\bar{x} 3.72)$ "use of bullet proof" was rated lowest, although still accepted as important. All the other security skills were highly rated as necessary for Office Managers to possess.

\subsection{Research Question 2: Mean responses of Stakeholders on the Security skills for protecting documents} in the office 


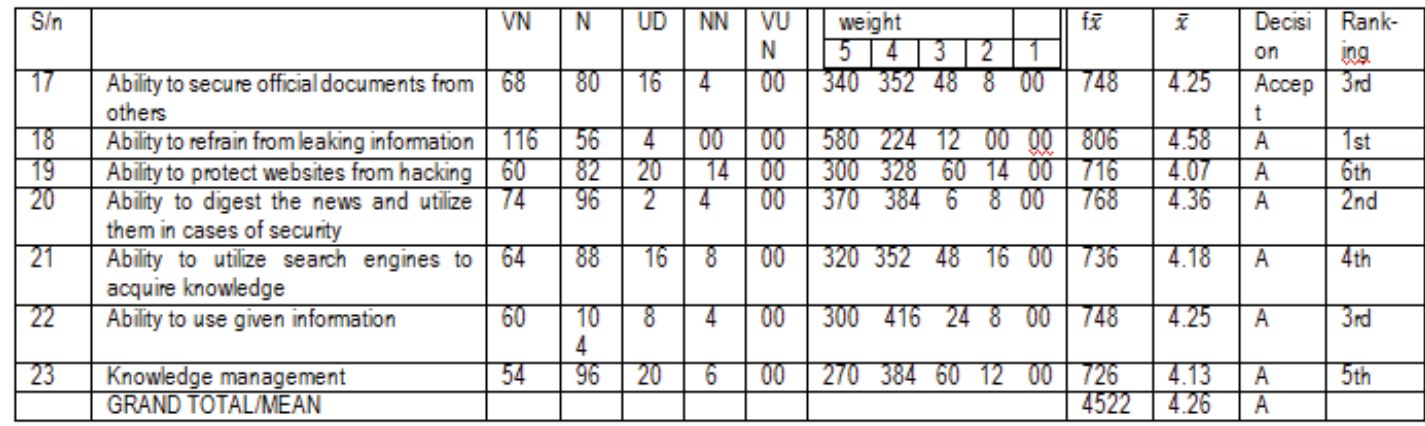

In order to protect documentations and other information (as revealed in the above table), respondents (stakeholders) indicated "refraining from leakage of information" as highest, hence item $18(\bar{x} 4.58)$ is ranked $1^{\text {st }}$. second in ranking is "ability to digest news/information in order to utilize them for security purpose" item 20 ( $\bar{x} 4.36)$, "using given information appropriately" item $22(\bar{x} 4.25)$ was rated $3^{\text {rd }}$ and "ability to utilize search engines to acquire knowledge" item $21(\bar{x} 4.18)$ was rated $4^{\text {th }}$. Other items were rated highly and so accepted as important security skills desired of Office Managers.

\subsection{Research Question 3: Mean responses on the importance of Security skills required by Office} Managers for protecting others on the job.

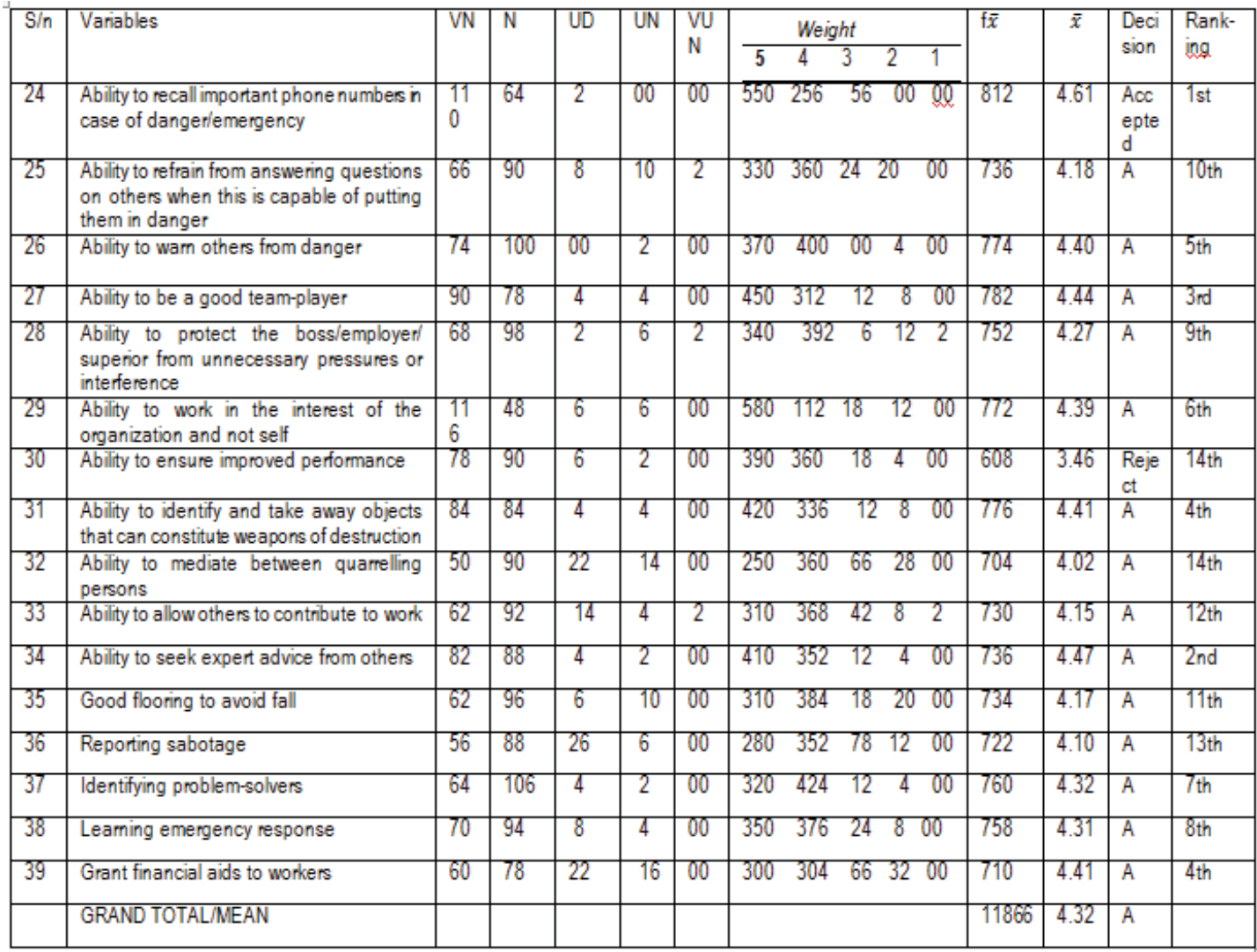


"Recalling important phone numbers for emergency ( $\bar{x} 4.61)$ was ranked highest followed by "seeking advice from others $(\bar{x} 4.47)$ and then $3^{\text {rd }}$ in ranking $(\bar{x} 4.44)$ was "being a good team-player" where $4^{\text {th }}$ rankings $(\bar{x} 4.41)$ were for "identifying and removing dangerous/destructive weapons" as well as "granting financial aids to workers". Others were also ranked highly (i.e. above $\bar{x} 3.50$ ), except "ability to ensure improved performance" ranked $15^{\text {th }}$ and last $(\bar{x} 3.46)$ was rejected as important.

9.4 Research Question 4: Mean responses on the importance of Security skills for protecting the environments of the Office Manager

\begin{tabular}{|c|c|c|c|c|c|c|c|c|c|c|c|}
\hline \multirow[t]{2}{*}{$S / n$} & \multirow[t]{2}{*}{ Variables } & \multirow[t]{2}{*}{$\mathrm{VN}$} & \multirow[t]{2}{*}{$\mathrm{N}$} & \multirow[t]{2}{*}{ UD } & \multirow[t]{2}{*}{ UN } & \multirow[t]{2}{*}{$\begin{array}{l}\mathrm{VU} \\
\mathrm{N}\end{array}$} & Weiqht & \multirow[t]{2}{*}{$f \bar{x}$} & \multirow[t]{2}{*}{$\overline{\bar{x}}$} & \multirow[t]{2}{*}{$\begin{array}{l}\text { Decisi } \\
\text { on }\end{array}$} & \multirow{2}{*}{$\begin{array}{l}\text { Rank- } \\
\text { ing }\end{array}$} \\
\hline & & & & & & & 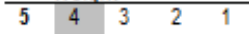 & & & & \\
\hline 40 & $\begin{array}{l}\text { Ability to identify a stranger (sensitivity to } \\
\text { the environment) }\end{array}$ & 102 & 70 & 2 & 2 & 00 & $\begin{array}{|lllll|}510 & 280 & 6 & 4 & 00 \\
\end{array}$ & 720 & 4.09 & $\begin{array}{l}\text { Accep } \\
\text { ted }\end{array}$ & 13th \\
\hline 41 & $\begin{array}{l}\text { Ability to call for repairs when there is } \\
\text { damage in the office }\end{array}$ & 68 & 96 & 4 & 6 & 2 & $\begin{array}{lllll}340 & 384 & 12 & 12 & 02\end{array}$ & 750 & 4.26 & $\bar{A}$ & 10 th \\
\hline 42 & $\begin{array}{l}\text { Abiily to ensure a clean and orderly } \\
\text { environment }\end{array}$ & 104 & 58 & 12 & 2 & $\infty 0$ & $\begin{array}{lllll}520 & 232 & 36 & 4 & 00\end{array}$ & 792 & 4.50 & A & 1st \\
\hline 43 & $\begin{array}{l}\text { Ability to gather knowledge on climate in } \\
\text { order to protect the environment }\end{array}$ & 36 & 106 & 14 & 16 & 2 & $\begin{array}{lllll}180 & 424 & 42 & 32 & 2\end{array}$ & 682 & 3.88 & A & 16th \\
\hline 44 & $\begin{array}{l}\text { Abiilty to advice appropriately on security } \\
\text { issues }\end{array}$ & 72 & 96 & 4 & 4 & $\infty 0$ & $\begin{array}{lllll}360 & 384 & 12 & 8 & 00\end{array}$ & 764 & 4.34 & $\bar{A}$ & 5 th \\
\hline 45 & Ability to sense terrorist presence & 80 & 70 & 16 & 10 & 00 & $\begin{array}{lllll}400 & 280 & 48 & 20 & 00\end{array}$ & 748 & 4.25 & A & 11th \\
\hline 46 & Fencing of environment & 66 & 94 & 8 & 4 & 4 & $\begin{array}{lllll}330 & 376 & 24 & 8 & 4\end{array}$ & 742 & 4.22 & $\bar{A}$ & 12 th \\
\hline 47 & Emergency exits & 86 & 80 & 2 & 8 & $\infty$ & $\begin{array}{lllll}430 & 320 & 6 & 16 & 00\end{array}$ & 772 & 4.39 & $\bar{A}$ & 3 तnd \\
\hline 48 & Training security personnel & 82 & 80 & 10 & 4 & $\infty 0$ & $\begin{array}{lllll}410 & 320 & 30 & 8 & 00\end{array}$ & 768 & 4.36 & $\bar{A}$ & 4th \\
\hline 49 & Security and other lighting services & 68 & 94 & 14 & 2 & $\infty 0$ & $\begin{array}{lllll}340 & 376 & 42 & 4 & 00\end{array}$ & 762 & 4.27 & A & 9th \\
\hline 50 & Processing phone data & 48 & 92 & 26 & 10 & 00 & $\begin{array}{lllll}240 & 368 & 78 & 20 & 00\end{array}$ & 706 & 4.01 & A & 15th \\
\hline 51 & Processing experience and recal for action & 36 & 120 & 14 & 6 & 00 & $\begin{array}{lllll}180 & 480 & 42 & 6 & 00\end{array}$ & 714 & 4.06 & A & 14th \\
\hline 52 & Protecting fiber optics & 32 & 78 & 40 & 22 & 4 & $\begin{array}{llll}160 & 312 & 120 & 44\end{array}$ & 640 & 3.64 & $\bar{A}$ & 19th \\
\hline 53 & $\begin{array}{l}\text { Provision of secunity cameras/CCTV } \\
\text { scanners }\end{array}$ & 88 & 62 & 18 & 6 & 2 & $\begin{array}{llll}440 & 248 & 54 & 12\end{array}$ & 756 & 4.30 & $\bar{A}$ & 8th \\
\hline 54 & Need for fire extinguishers & 104 & 64 & 2 & 4 & 2 & $\begin{array}{llll}520 & 256 & 6 & 8\end{array}$ & 792 & 4.50 & $\bar{A}$ & 1st \\
\hline 55 & Need for fire service & 84 & 72 & 8 & 10 & 00 & $\begin{array}{lllll}420 & 296 & 24 & 20 & 00\end{array}$ & 760 & 4.32 & A & 6 th \\
\hline 56 & Ensure better farming techniques around & 24 & 84 & 26 & 38 & 4 & $\begin{array}{lllll}120 & 336 & 78 & 76 & 4\end{array}$ & 614 & 3.49 & Reject & 20 th \\
\hline 57 & $\begin{array}{l}\text { Maintaining peaceful and harmonious } \\
\text { environment }\end{array}$ & 68 & 92 & 6 & 6 & 00 & $\begin{array}{lllll}340 & 368 & 18 & 12 & 00\end{array}$ & 758 & 4.31 & A & 7 th \\
\hline 58 & Good incentives to workers & 90 & 72 & 10 & 4 & 00 & $\begin{array}{lllll}450 & 288 & 30 & 8 & 00\end{array}$ & 776 & 4.41 & A & 2nd \\
\hline 59 & Give merit awards to selected persons & 40 & 84 & 30 & 14 & 8 & $\begin{array}{lllll}200 & 336 & 90 & 28 & 8\end{array}$ & 662 & 3.76 & A & 17th \\
\hline 60 & Providing water hydrant & 38 & 76 & 42 & 16 & 00 & $\begin{array}{lllll}190 & 304 & 126 & 32 & 00\end{array}$ & 652 & 3.71 & A & 18th \\
\hline & GRAND TOTALIMEAN & & & & & & & $\begin{array}{l}7206 \\
24\end{array}$ & $4 . .15$ & $\bar{A}$ & \\
\hline
\end{tabular}

From the above table 4, the respondents ranked items 42 and 54 as $11^{\text {st }}$ i.e. "ability to ensure a clean and orderly environment" and "need for fire extinguisher" ( $\bar{x} 4.50)$ while item 58 "good incentives to workers" $(\bar{x} 4.41)$ was ranked $2^{\text {nd }}$. Item 47 "emergency exits" $(\bar{x} 4.39)$ was ranked $3^{\text {rd }}$ in rating and item 48 "training security personnel" ( $x 4.36)$ was ranked $4^{\text {th }}$. Apart from item 56 "ensuring better farming techniques around the environment" $(x 3.49)$ which was ranked $20^{\text {th }}$ and last, and subsequently rejected because the rating fell below the acceptable 3.50; all the other items were rated well above the acceptable $x 3.50$. 


\section{Discussion and Implication of Findings}

Protecting oneself was perceived by stakeholders as very crucial in all aspects of life hence, the highest rating given to emergency response. It then appears surprising that Nigeria's emergency response is the lowest in the world. The arrivals of her emergency agencies (as in the case of Dana Air crash in 2012 and the recent insurgency attacks in 2013) bear credible testimonies of their late-sided habits. The need to keep secrets about oneself and to prevent avoidable dangers is signs of caution and carefulness which are necessary ingredients for not only protecting oneself but also protecting the organization. "Honesty is the best policy" and respondents agreed with this in their high rating for honesty while sensing trouble was also considered very necessary as a security skill for Office Managers.

Documents and information were equally perceived by the respondents as important in security. Note the highest rating under protecting documents in the office. No wonder the fierce reaction of American government towards the Wiki-leaks discovery (2010) and that of Edward Snowden recently (June 2013). Sometimes this information signify the life and health of those concerned and so whistle blowing should hands off such areas, if there is no intention of massive destruction. Using news and/or information to arm oneself in protecting the office as well as shielding official documents from public eyes were rated highly. However, the lowest ranking (though with high rating of $x 4.07$ ) was ascribed to "ability to protect websites from hacking" and is an indication that knowledge of Information and Communication Technology (ICT) and its intricacies are yet to be fully understood by our stakeholders.

In protecting others, the stakeholders rated "ability to recall important phone numbers in case of danger/emergency as highest. Police numbers, fire service numbers and those of other emergency numbers are very crucial in helping others survive in our environment. This is where the participatory dimension is most essential as expressed in www.mirriam-webster.com/dictionary/participatory that this involves collaborative or more open activities in solving problems concerning others. Senyucel (2009) had identified security as one of the very delicate but crucial reasons why employees and indeed people as a whole join in groups; hence we see pockets of unions and social groups with the aim of fulfilling this need which oftentimes lead to powerful collective bargaining power, social needs and sense of belonging.

The protection of the environment through other means were rated highly except as it concerns the land; hence the rejection of good farming technique as important. This is in consonance with Madumere (2012) findings that Nigerians lack the necessary awareness on the ingredients of the environment and these could lead to environmental degradation culminating into climate change and other environment hazards.

\section{Conclusion and Recommendation}

The study has revealed the fact that security is everybody's business indeed because all and everything including the economy suffers in the face of insecurity. Protection in this regard should be from external and internal forces in form of threats to life and property, threats to classified information and threats to environment (including climate). The need for Office Managers and indeed citizens of nations to acquire security skills was established; especially in the face of hunger, terrorism, leakages of classified security information, climate change and other avoidable hazards ravaging countries of the world. When people consciously and unconsciously protect themselves, others, information, organizations, and the environment, the world would be a better place for us all. The measurable state of a nation to overcome threats of multidimensional nature to her territory which invariably affects all within the state, including human, animals, information, environment, relationships, economy, natural resources, etc, demands periodic assessment with the hope of detecting insurgency or impending dangers. This is why the participatory dimension of fighting insecurity was deemed very crucial to Nigeria and indeed all nations.

The study recommended the following:

1. Teaching security skills at all levels of education from primary up to tertiary levels. 
2. Security laboratories for simulations and brainstorming should be set up in institutions and administrative colleges.

3. Fire service stations should be made more functional.

4. Community policing should be encouraged and closely monitored by enforcement agencies.

5. Security should be included in the next phase of MDG (Millennium Development Goals).

6. Security packages should be provided for securing Computers and Laptops.

7. Security cameras should be provided for institutions, offices and strategic places in the communities.

8. National Emergency Management Agency (NEMA), fire service and other security/emergencies bodies should be restructured and transformed to be more responsive to emergency situations.

9. Enforcement of the guns and small arms law should be intensified.

10. All those living in insecurity prone areas should from time to time be given free stress treatment, to be funded by government.

\section{References}

Adesola, S.A. (2012). Overcoming the challenges of sustainable development through Science And Technology Education. Journal of Educational and Social Research, 2(7), 11-19.

Cheetham, G. and Chivers, G. (2005). Profession, Competence and Informal Learning. United Kingdom: Edward Elgar Publishing Ltd.

Dreyfus, S.E. and Dreyfus, H.L. (1990). A five-stage model of mental activities involved in Directed skill acquisition. Washington, D.C.: Storming Media.

En.Wikipedia.org/wiki/skill. Accessed on 7th of June, 2013.

En.wikipedia.org/wiki/security, job-security. Retrieved on 5th day of June, 2013.

https:/l.en.wikipedia.org/wiki/stakeholder. Retrieved 5th June, 2013.

Madumere, A.J. (2012). Assessing the level of environmental awareness of non-science students of Colleges of Education in Rivers State, Nigeria. Journal of Educational and Social Research, 2(7), 69-74.

Mohan, G. (2001). Participatory Development. www.apa.org>publications>APA. Retrieved 7th June, 2013.

www.sans.org/course/security-essentials-bootcamp-style. Retrieved 5th June, 2013.

www.merriam-webster.com/dictionary/participatory. Retrieved 9th May, 2013.

www.bankrate.com/finance/financial. retrieved 5th June, 2013.

John Olstik (2013). (www.nada.org>informationtechnology>ITtips. Retrieved 5th June, 2013.

Zorlu Senyucel (2009). Managing the Human Resources in the 21st Century. E-books at book Boon.com: Zorlu Senyucel $\&$ Ventus Publishing Aps. 